\title{
鋼繊維補強コンクリートの一軸引張および せん断に対する変形挙動のモデル化
}

\author{
椿 龍哉 ${ }^{* 1} \cdot$ 荒井知久 ${ }^{* 2} \cdot$ 保永武徳 ${ }^{* 3}$
}

\begin{abstract}
概 要 鋼繊維補強コンクリートの挙動は，構造物の耐久性に影響をおよぼすひび割れ幅などに関係するた め, 重要な検討事項である。本研究では, 一軸引張およびせん断を受ける鋼繊維補強コンクリート供試体の, 各々の荷重に対する変形挙動を実験的に調べた。実験では鋼繊維の混入率, 繊維形状および付着長の影響を検 討した。コンクリートは高強度を対象とした。実験結果から, 鋼繊維補強コンクリートの一軸引張およびせん 断に対する変形挙動をモデル化した。
\end{abstract}

キーワード：鋼繊維補強コンクリート, 一軸引張, せん断, 変形挙動, 繊維形状, 付着長, モデル化

\section{1.はじめに}

鋼繊維補強コンクリート (SFRC) は, 鋼繊維の付着 力と引抜け抵抗によってひび割れ後も荷重を伝達する が，荷重の伝達の程度は鋼繊維の分布状態，配向状態な どに依存すると考えられる。また，ひび割れ面において は，個々の鋼繊維の架橋効果の他に，鋼繊維間の相互作 用，母材の凹凸や骨材のかみ合い，および摩擦などが関 係し，それらが荷重に抵抗していると思われる。鋼繊維 補強コンクリートの変形特性を把握するためには, これ らの要因を明らかにする必要がある。

鋼繊維補強コンクリートの䋊維の引抜け挙動について は，個々の繊維を対象とした実験的研究がこれまでにな されている ${ }^{1,2,3,3,4)}$ 。また, 鋼繊維補強コンクリート全体の 挙動を調べた研究 ${ }^{5)}$ や種々の形状の鋼繊維を検討した研 究 ${ }^{6)}$ がある。

これらの実験的研究により鋼繊維補強コンクリートの 種々の力学的特性が明らかにされてきた。一方, 鋼繊維 補強コンクリートの変形挙動を表現するための構成モデ ル`を構築するためには, 個々の繊維の引抜け特性の数 学的モデル化 ${ }^{8,9,1,10)}$ の他に個々の繊維の引抜け特性を合成 する手法の確立や, 繊維間の相互作用の検討が必要であ る。

著者らはこれまでに個々の鋼繊維が一軸引張とせん断 を受ける場合の変形特性を繊維形状と繊維方向角をパラ メータとして調べている ${ }^{33,4)}$ 。鋼繊維補強コンクリート全 体の挙動を表現する構成モデルを構築するためには, 鋼
繊維補強コンクリート供試体の挙動を調べ，個々の鋼繊 維の挙動との対応を明らかにする必要がある。また, 上 記のパラメータのほかに, 鋼繊維の付着長の影響を明ら かにすることが必要である。鋼繊維の引抜け特性におよ ぼす付着長の影響に関する研究はこれまでにもなされて いるが11), 鋼纎維の種類に応じた系統的なデータがモデ ル化には必要である。

本研究では, これらのことを考慮し, 鋼繊維補強コン クリートの一軸引張とせん断に対する特性におよぼす纎 維形状, 繊維混入率の影響を実験的に調べ, その結果を もとに, 繊維方向角と付着長をパラメータとして考慮し たモデルを導くことを試みた。

\section{2 . 実験概要}

\section{1 使用材料}

使用材料は表一 1 に示される。セメントは普通ポルト ランドセメント, 細骨材は最大寸法 $5 \mathrm{~mm}$ の川砂である。 鋼綫維の形状と特性は表一2に, 形状の詳細は図一1に 示す。鋼繊維の種類はインデント加工された伸線ファイ バー（直線型 $\mathrm{S} 1, \mathrm{~S} 2$ ), 両端部にフックを付けた伸線フ アイバー (フック型 $\mathrm{HK}$ ), および両端部に突起を付け た溶解抽出法によるファイバー（端部定着型 AN）の 4 種類である。アスペクト比は直線型（S1）が45.5, 直線 型（S2）とフック型（HK）が50, 端部定着型 (AN) が60である。直線型（S2）は直線型（S1）よりも表面 のインデント加工による凹凸が大きい。また，供試体内

* 1 横浜国立大学教授 工学部建設学科 (正会員)

*2 横浜国立大学大学院（現在, オリエンタルコンサルタンツ(株)

*3 横浜国立大学大学院 博士課程前期 
部を均一な状態にするため粗骨材は使用せず，母材はモ ルタルとした。母材がコンクリートの場合は，粗骨材と 鋼瀻維の相互作用等が問題になるが，本研究では現象を 単純化するためにモルタルを使用した。

\section{2 供試体と配合}

一軸引張実験およびせん断実験に用いた供試体の種類

表一1 使用材料

\begin{tabular}{|c|c|}
\hline 材料 & 種類（主成分等） \\
\hline 水 & 上水道水 $\left(20^{\circ} \mathrm{C}\right)$ \\
\hline セメント & 普通ポルトランドセメント（此重：3.16） \\
\hline 細骨材 & 川砂（表乾比重：2.47, 粗粒率：2.28） \\
\hline 混和剤 & 高性能AE減水荗（アニオン型特殊高分子活性剂） \\
\hline
\end{tabular}

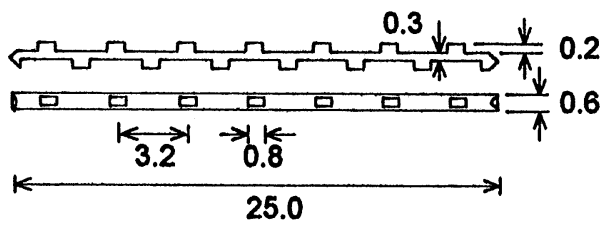

(a) 直線型(S1)

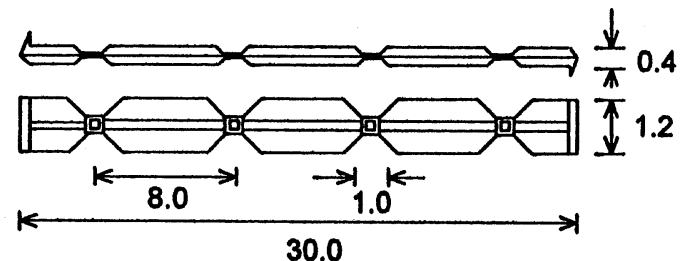

(b) 直線型(S2)

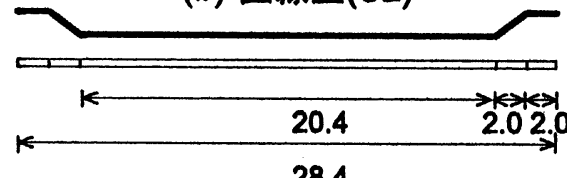

28.4

(c) フック型(HK)

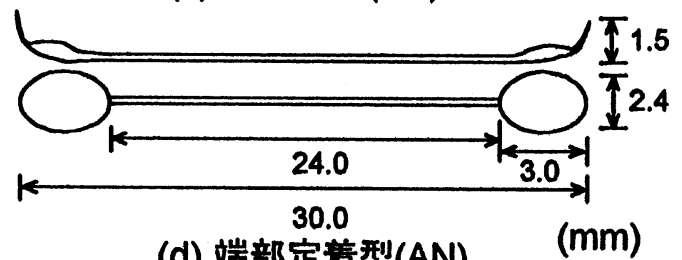

(d) 端部定着型(AN)

I 2.0

図-1 鋼繊維の形状

表一2 使用した鋼繊維の形状と特性

\begin{tabular}{|c|c|c|c|c|c|}
\hline 鋼繊維 & $\begin{array}{l}\text { 直径 }^{*} \\
(\mathrm{~mm})\end{array}$ & $\begin{array}{l}\text { 長さ } \\
(\mathrm{mm})\end{array}$ & $\begin{array}{l}\text { アスペ } \\
\text { クト比 }\end{array}$ & $\begin{array}{l}\text { 引張強度 } \\
\left(\mathrm{N} / \mathrm{mm}^{2}\right)\end{array}$ & 製造方法等 \\
\hline $\begin{array}{c}\text { 直線型-1 } \\
\text { (S1) }\end{array}$ & 0.55 & 25.0 & 45.5 & 980 & 鋼線切断法 \\
\hline $\begin{array}{l}\text { 直線型-2 } \\
(\mathrm{S} 2)\end{array}$ & 0.60 & 30.0 & 50.0 & 980以上 & 鋼線切断法 \\
\hline $\begin{array}{c}\text { フック型 } \\
(\mathrm{HK})\end{array}$ & 0.60 & 30.0 & 50.0 & 1078 以上 & 鋼線切断法 \\
\hline $\begin{array}{c}\text { 端部定着型 } \\
\text { (AN) }\end{array}$ & 0.50 & 30.0 & 60.0 & 平均 980 & $\begin{array}{l}\text { 溶解抽出法 } \\
\text { (ステンレス) }\end{array}$ \\
\hline
\end{tabular}

[注］* 断面が円形でない鋼繊維の直径は換算径である。
と配合は表一3に示す。モルタルの配合は，高強度コン クリートを想定し， $W / C=30 \%, S / C=100 \%$ ある。 高性能 $\mathrm{AE}$ 減水剂の使用量は $4 \mathrm{~kg} / \mathrm{m}^{3}$ で一定である。一 軸引張実験およびせん断実験に用いた供試体の形状と寸 法は図一2, 図一3に示す。供試体中央部の厚さは $100 \mathrm{~mm}$ である。各々の種類の供試体は 2 体作製し, 実 験結果にはそれらの平均值を示す。中央部にひび割れ面 を想定し, ポリエステルフィルムを用いて一軸引張実験 用の供試体には想定ひび割れ面の左右両側に, せん断実 験用の供試体にはせん断面の左右両側に深さ $10 \mathrm{~mm}$ のス リットを設けた。また，他の部分を鉄筋（D6, D10）で 補強した。鋼繊維の混入率 $\left(V_{f}\right)$ は $1 \% ， 2 \%$ とした。 鋼繊維は供試体製作時に想定したひび割れ面に対しラン ダムな配向状態となるように所定の量を混入した。練混

表一3 供試体と配合

(a) ランダム配向供試体

\begin{tabular}{|c|c|c|c|c|c|c|c|}
\hline \multirow{2}{*}{$\begin{array}{l}\text { 実 } \\
\text { 験 }\end{array}$} & \multirow{2}{*}{ 供試体 ${ }^{*}$} & \multicolumn{2}{|c|}{ 鋼繊維 } & \multirow{2}{*}{$\begin{array}{c}\text { 水セメ } \\
\text { ント比 } \\
\mathrm{W} / \mathrm{C} \\
(\%)\end{array}$} & \multicolumn{3}{|c|}{$\begin{array}{l}\text { 単位量 } \\
\left(\mathrm{kg} / \mathrm{m}^{3}\right)\end{array}$} \\
\hline & & $\begin{array}{c}\text { 混入率 } \\
(\%)\end{array}$ & 形状 & & $\begin{array}{l}\text { 水 } \\
\mathrm{W}\end{array}$ & $\begin{array}{c}\text { セメント } \\
\text { C }\end{array}$ & $\begin{array}{l}\text { 砂 } \\
\mathrm{S}\end{array}$ \\
\hline \multirow{8}{*}{$\begin{array}{l}\text { 軸 } \\
\text { 引 } \\
\text { 張 }\end{array}$} & $T-R-S 1-1$ & 1.0 & \multirow{2}{*}{ S1 } & \multirow{8}{*}{30} & \multirow{8}{*}{292} & \multirow{8}{*}{974} & \multirow{8}{*}{974} \\
\hline & $T-R-S 1-2$ & 2.0 & & & & & \\
\hline & $T-R-S 2-1$ & 1.0 & \multirow{2}{*}{ S2 } & & & & \\
\hline & $T-R-S 2-2$ & 2.0 & & & & & \\
\hline & $T-R-H K-1$ & 1.0 & \multirow{2}{*}{$\mathrm{HK}$} & & & & \\
\hline & $T-R-H K-2$ & 2.0 & & & & & \\
\hline & $T-R-A N-1$ & 1.0 & \multirow{2}{*}{ AN } & & & & \\
\hline & $T-R-A N-2$ & 2.0 & & & & & \\
\hline \multirow{8}{*}{$\begin{array}{l}\stackrel{\text { せ }}{ん} \\
\text { 断 }\end{array}$} & $S-R-S 1-1$ & 1.0 & \multirow{2}{*}{ S1 } & \multirow{8}{*}{30} & \multirow{8}{*}{292} & \multirow{8}{*}{974} & \multirow{8}{*}{974} \\
\hline & $S-R-S 1-2$ & 2.0 & & & & & \\
\hline & $S-R-S 2-1$ & 1.0 & \multirow{2}{*}{ S2 } & & & & \\
\hline & $S-R-S 2-2$ & 2.0 & & & & & \\
\hline & $S-R-H K-1$ & 1.0 & \multirow{2}{*}{ HK } & & & & \\
\hline & $S-R-H K-2$ & 2.0 & & & & & \\
\hline & $S-R-A N-1$ & 1.0 & \multirow{2}{*}{ AN } & & & & \\
\hline & $S-R-A N-2$ & 2.0 & & & & & \\
\hline
\end{tabular}
(b) 付着長用供試体

\begin{tabular}{|c|c|c|c|c|c|c|c|}
\hline \multirow{2}{*}{$\begin{array}{l}\text { 㤅 } \\
\text { 騟 }\end{array}$} & \multirow{2}{*}{ 供試体* } & \multicolumn{2}{|c|}{ 鋼繊維 } & \multirow{2}{*}{$\begin{array}{l}\text { 水セメ } \\
\text { ント比 } \\
W / C \\
(\%)\end{array}$} & \multicolumn{3}{|c|}{ 単位量 $\left(\mathrm{kg} / \mathrm{m}^{3}\right)$} \\
\hline & & $\begin{array}{c}\text { 付着長 } \\
(\mathrm{mm})\end{array}$ & $\begin{array}{l}\text { 角度 } \\
\text { (度) }\end{array}$ & & $\begin{array}{l}\text { 水 } \\
\mathrm{W}\end{array}$ & $\begin{array}{c}\text { セメント } \\
\mathrm{C}\end{array}$ & $\begin{array}{l}\text { 砂 } \\
\mathrm{S}\end{array}$ \\
\hline \multirow{6}{*}{$\begin{array}{l}\text { 軸 } \\
\text { 引 } \\
\text { 張 }\end{array}$} & $T-0-12.5$ & 12.5 & & \multirow{6}{*}{30} & \multirow{6}{*}{292} & \multirow{6}{*}{974} & \multirow{6}{*}{974} \\
\hline & $T-0-8.0$ & 8.0 & 0 & & & & \\
\hline & $T-0-4.0$ & 4.0 & & & & & \\
\hline & $T-45-12.5$ & 12.5 & \multirow{3}{*}{45} & & & & \\
\hline & $T-45-8.0$ & 8.0 & & & & & \\
\hline & $T-45-4.0$ & 4.0 & & & & & \\
\hline \multirow{3}{*}{$\begin{array}{l}\stackrel{せ}{\swarrow} \\
\text { 断 }\end{array}$} & $S-0-12.5$ & 12.5 & \multirow{3}{*}{0} & \multirow{3}{*}{30} & \multirow{3}{*}{292} & \multirow{3}{*}{974} & \multirow{3}{*}{974} \\
\hline & $S-0-8.0$ & 8.0 & & & & & \\
\hline & $S-0-4.0$ & 4.0 & & & & & \\
\hline
\end{tabular}

[注］（a）＊供試体記号：(一軸引張 $T$ ，せん断 $S)-(R:$ ランダム配向 $)$ (瀻維形状 $\left[\right.$ 図 -1 参照]) - (䋐維混入率 $\left.V_{f}(\%)\right)$

(b) * 供試体記号 : (一軸引張 $T$, 也ん断 $S$ ) - (繊維方向角 $\theta\left(^{\circ}\right.$ ) [図 $-2,3$ 参照] - (付着長 $(\mathrm{mm})$ ) ; 繊維形状はS1, 繊維本 数は32本 
ぜはオムニミキサーを用いて行い，モルタルの練混ぜ時 間は平均 4 分間である。事前にセメントと砂を 2 分間空 練りした。

供試体は温度 $20^{\circ} \mathrm{C}$ で湿気養生の後, 材齢 1 日で脱型 後，材齢 28 日になるまで温度 $20{ }^{\circ} \mathrm{C}$ の水中で養生した。 実験時の材齢は28日である。

付着長の影響を調べるための供試体は，形状寸法は上 記の供試体と同じである。一軸引張実験用とせん断実験 用の供試体ともに，ひび割れ面を想定した不連続面を中 央に設けている。不連続面にはビニールシートを 2 枚挿 入することにより 2 個のブロックの付着を切っている。 所定の付着長と繊維方向角を与えるために, 鋼繊維は硬 質発泡スチロールのブロックに挿入し，そのブロックを 型枠として用いて一方のブロックを打設し, 材齢 1 日で 脱型後, 他方のブロックを打設した。材齢 2 日で脱型す るまでは湿気養生をした。脱型後の養生, 実験時材齢は 上記の場合と同じである。鉄筋による補強はしていない。 鋼繊維は直線型（S1）を用い，不連続面に格子状（縦
$10 \mathrm{~mm}$ ，横 $20 \mathrm{~mm}$ 間隔）に 8 行 4 列で 32 本配置した ${ }^{4)}$ 。 付着長は $12.5 \mathrm{~mm}, 8.0 \mathrm{~mm}, 4.0 \mathrm{~mm}$ の 3 種類, 繊維方向 角 $\theta$ は $0^{\circ}, 45^{\circ}$ の 2 種類について調べた。繊維方向角 $\theta$ の定義は図一2, 図一 3 に示す。

\section{3 載荷方法}

一軸引張実験の載荷方法は図一 4 に示す。供試体の上 部ブロックを支持し，下部ブロックを押し下げることに より, 引張力を与えた。せん断実験の載荷方法は図ー5 に示す。プッシュオフ型の供試体に上下に圧縮力を加え ることにより，せん断面にせん断力を与えた。荷重はア ムスラ一型万能試験機で載荷し, 載荷速度は, 最大荷重 に達するまでは, 纎維 1 本当たりの荷重速度が平均で $0.25 \mathrm{~N} / \mathrm{s}$ となるように調節した。この值は繊維の付着試 験方法 ${ }^{12}$ の載荷速度の約 $1 / 3$ に相当し，急激な変形を防 ぐために設定した。荷重はロードセルにより，また，一 軸引張実験の引抜け変位, せん断実験のせん断面の開口

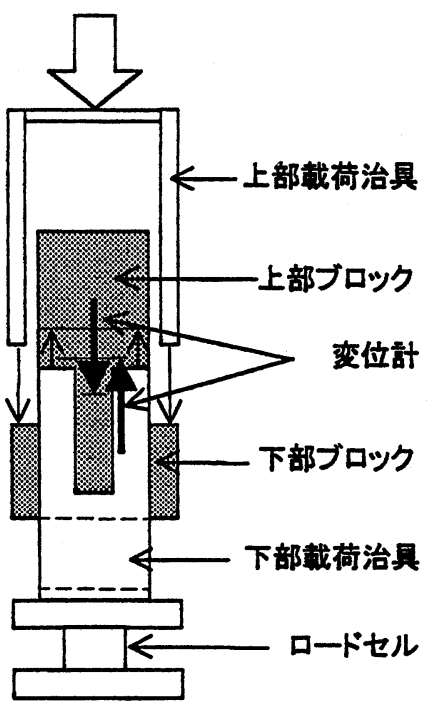

図－4 一軸引張実験の載荷方法

図一－軸引張実験の供試体

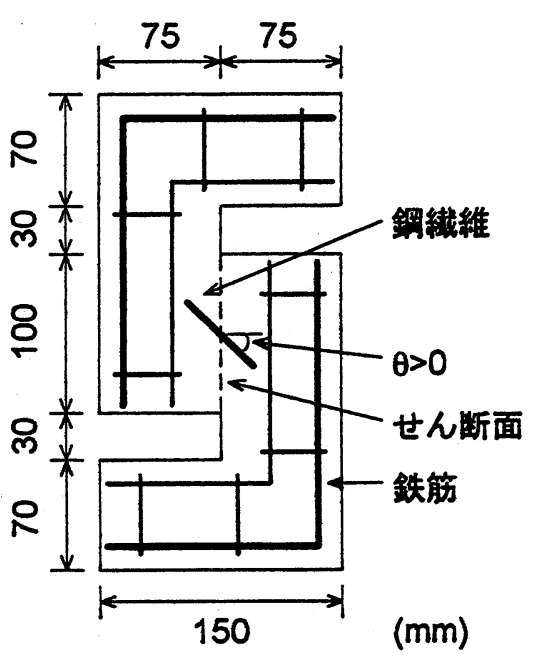

図一3 せん断実験の供試体

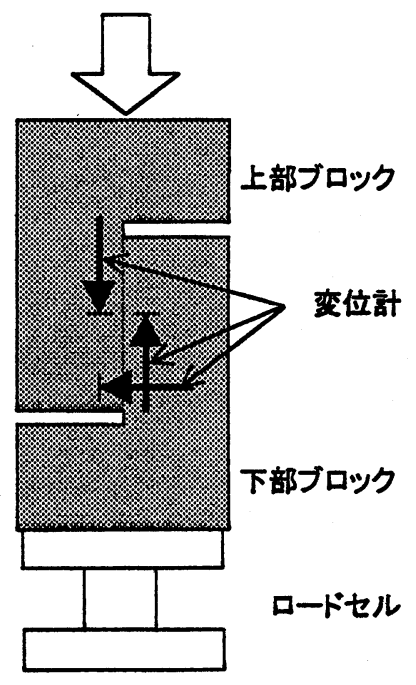

図－5 せん断実験の載荷方法 
幅（両者ともに「ひび割れ幅」と呼ぶ）およびせん断変 位は，供試体の前後面で各々の相対变位を高精度型変位 計により計測した。計測位置は，一軸引張実験のひび割 れ幅とせん断実験のせん断変位は供試体中央の 2 箇所, せん断害験のひび割れ幅はせん断面の上下端の 2 箇所で ある。実験結果としては各々の平均値を示す。

\section{3 . 実験結果}

\section{1 材料特性}

供試体に用いたモルタルの圧縮強度を, 直径 $50 \mathrm{~mm}$, 高さ $100 \mathrm{~mm}$ の円柱供試体を用いて求めた。一軸引張実 験用の供試体の圧縮強度の平均值は，ランダム配向供試 体で $54.5 \mathrm{~N} / \mathrm{mm}^{2}$ ，付着長用供試体で $55.0 \mathrm{~N} / \mathrm{mm}^{2}$ である。 せん断実験用の供試体の圧縮強度の平均值は，ランダム 配向供試体で $61.3 \mathrm{~N} / \mathrm{mm}^{2}$, 付着長用供試体で $56.1 \mathrm{~N} / \mathrm{mm}^{2}$ である。試験時の材齢は28日である。
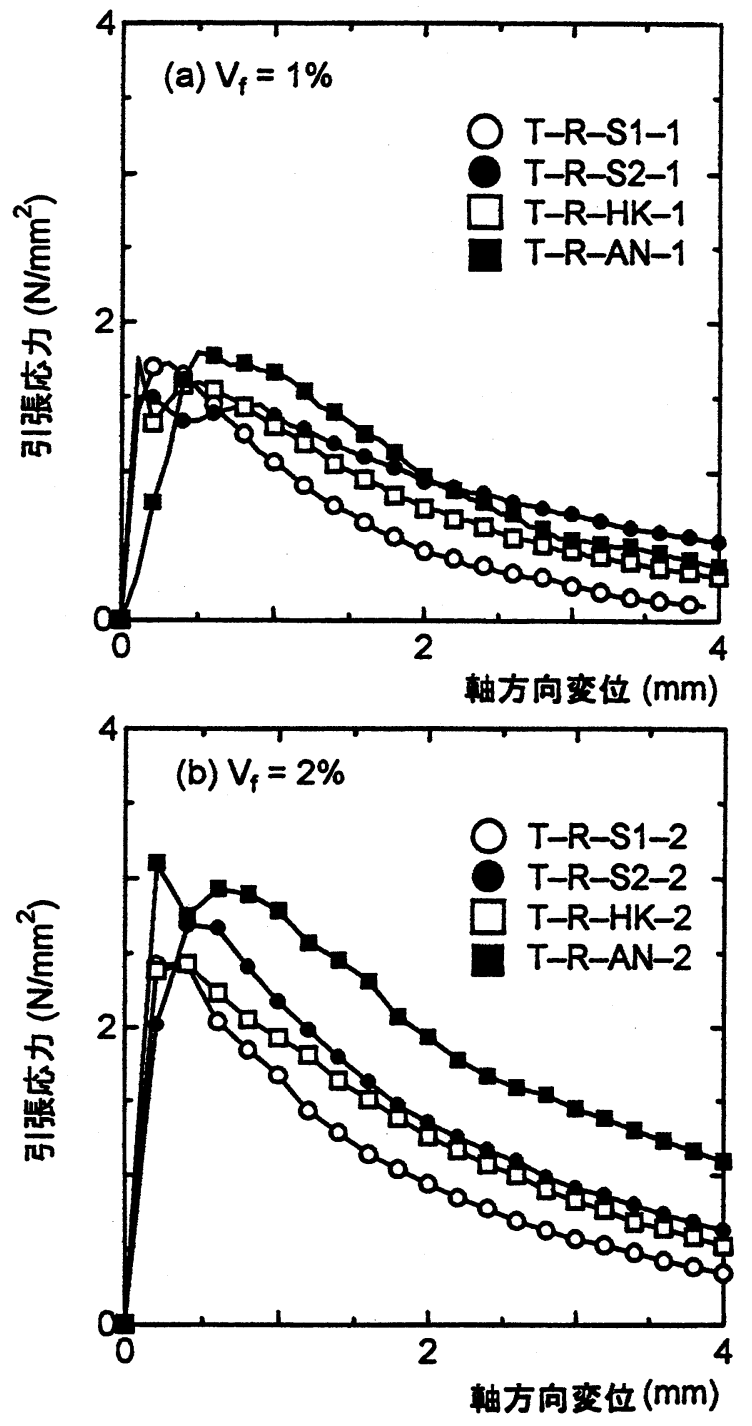

図一6 引張力と軸方向変位の関係

\section{2 一軸引張に対する挙動}

荷重変位関係は鋼繊維混入率 $\left(V_{f}\right)$ が $1 \%, 2 \%$ の のを図ー6に示す。縦軸は引張力をひび割れ面の面積で 割った值を示している。ひび割れ面の単位面積当たりの 最大引張力は $V_{f}$ が $1 \%$ のき各種形状の繊維の間に顕著 な差はみられない。 $V_{f}$ が $2 \%$ のきは直線型（S2）と端 部定着型（AN）が比較的大きな值を示す。繊維形状が 直線型（S1）の場合は，ひび割れを想定した面にひび 割れが直線的に形成され，直線型（S2）の場合は，ス リット以外からもひび割れた。フック型 $(\mathrm{HK})$, 端部定 着型（AN）ではひび割れが直線的に入らず，ひび割れ 面に凹凸ができた。

\section{3 せん断に対する挙動}

荷重変位関係は鋼繊維混入率 $\left(V_{f}\right)$ が $1 \%, 2 \%$ の のを図ー7に示す。縦軸はせん断力をせん断面の面積で 割った值を示している。せん断面の単位面積当たりの最 大せん断力および最大せん断力時の変位は，フック型
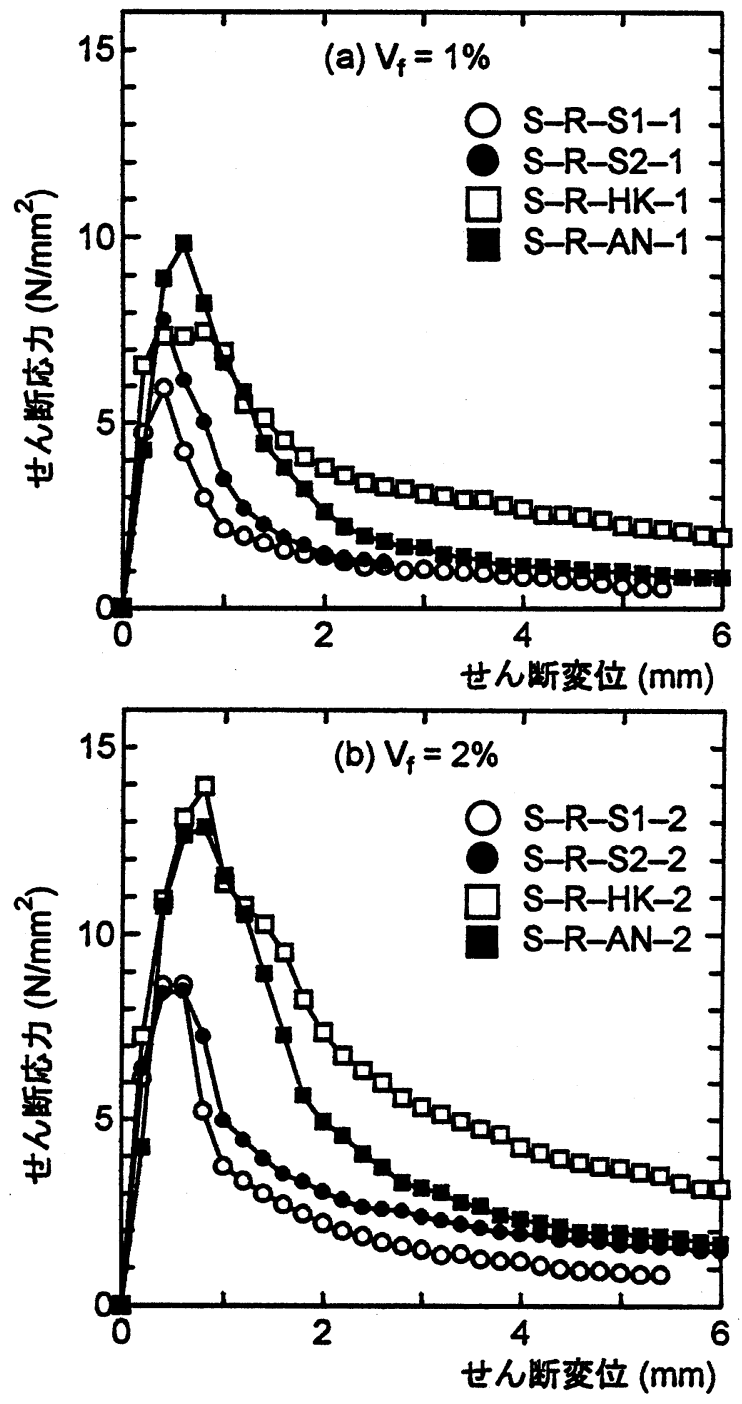

図-7 せん断カとせん断変位の関係 

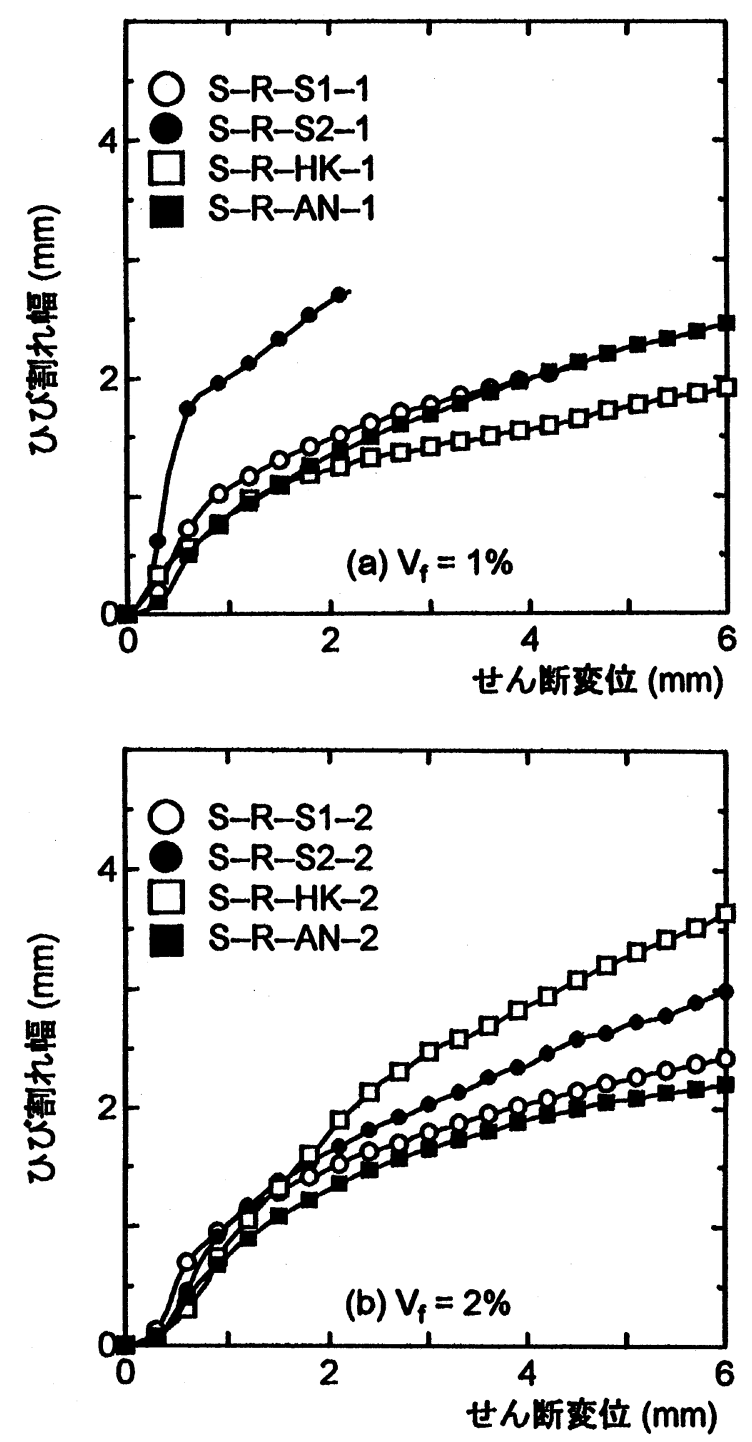

図一8ひび割れ幅とせん断変位の関係

$(\mathrm{HK})$ ，端部定着型 (AN) が大きい。繊維形状が直線型 (S1)，端部定着型（AN）の場合は，ひび割れが直線的 に入り，直線型（S2）ではひび割れが湾曲し，繊維や モルタル面の凹凸のかみ合い効果の影響が大きくなると いう結果となった。

せん断変位とひび割れ幅の関係は図－8に示す。ひび 割れ幅はせん断変位の増加にともない増加することが示 されている。纎維混入率の影響は顕著ではない。なお, 繊維混入率 $1 \%$ のきの直線型（S2）のひび割れ幅の 増加が他の種類の鋼繊維のものよりも大きいのは，ひび 割れ面の凹凸，および鋼繊維の偏在によると考えられ る。

引張，せん断ともに繊維混入率 $1 \%$ と $2 \%$ を比較する と, 繊維量の増加にともない, 強度が増加することがわ かる。引張では，基礎実験として行った繊維混入率 $0 \%$ のときの強度が $1.53 \mathrm{~N} / \mathrm{mm}^{2}$ であり，4 種類の鋼繊維の 強度増加率は繊維混入率 $1 \%$ のとき平均 $11 \%$, 繊維混 入率 $2 \%$ のとき平均 $76 \%$ となった。一方，せん断では，
繊維混入率 $0 \%$ \%さき強度が $4.50 \mathrm{~N} / \mathrm{mm}^{2}$ であり，4 種類の鋼繊維の強度増加率は絨維混入率 $1 \%$ のとき平均 $75 \%$, 繊維混入率 $2 \%$ のき平均 $146 \%$ となった。全体 として最大荷重までの変位は小さく, 実際の鋼繊維補強 コンクリートのひび割れ抑制効果が確認できる。また, 荷重方向変位が大きくなるとモルタルの剥離などが起こ り，鋼繊維を支える母材の破壊によって鋼繊維補強コン クリートの強度が減少することがわかった。

\section{4 鋼繊維の付着長の影響}

一軸引張特性におよぼす付着長の影響は，図一9に示 される。付着長が短くなるにともない, 最大引張力と最 大引張力時のひび割れ幅が減少する傾向がみられる。ま た，繊維方向角が大きくなると最大引張力と最大引張力 時のひび割れ幅がともに減少することがわかる。

せん断特性におよぼす付着長の影響は，図一10に示 される。一軸引張の場合と異なり，付着長の最大せん断

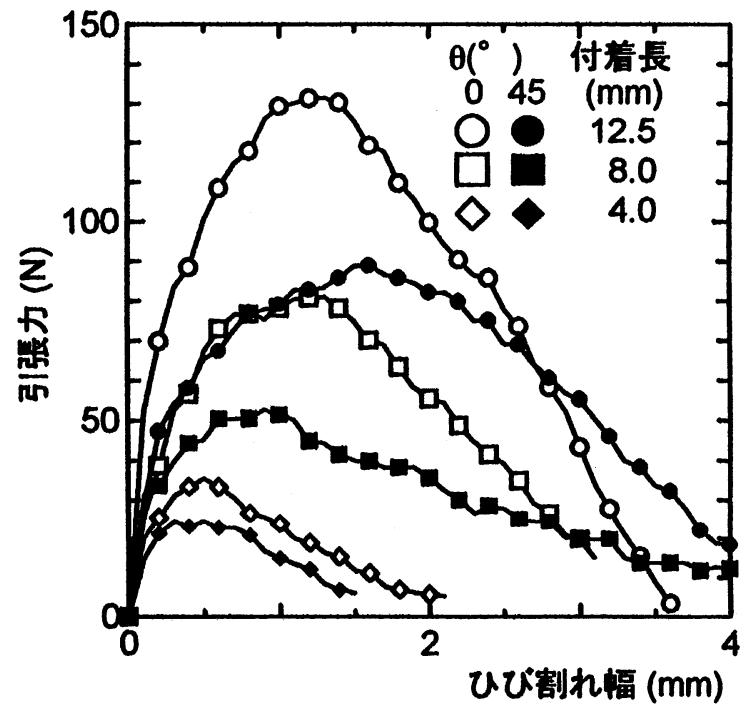

図-9 引張力とひび割れ幅の関係（付着長の影響）

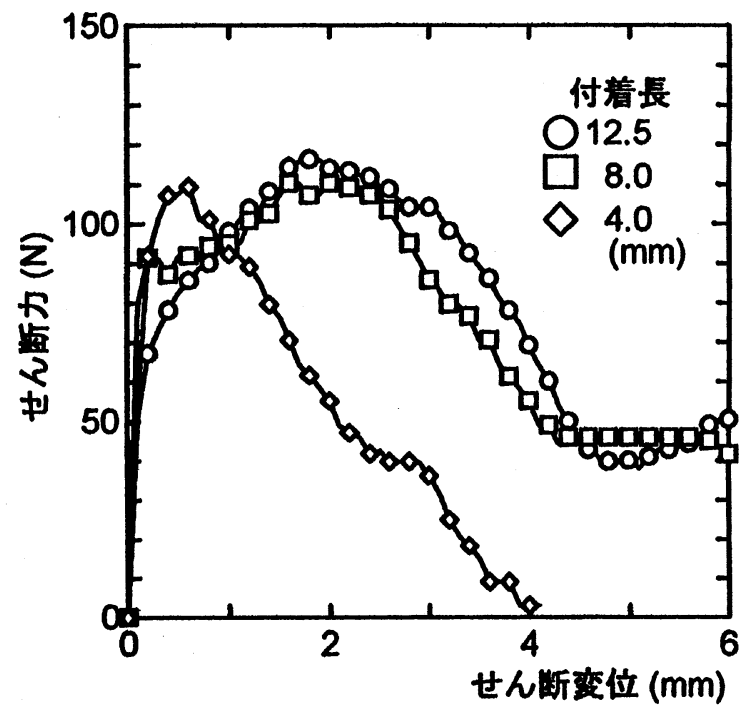

図一10 せん断力とせん断変位の関係（付着長の影響） 
力におよぼす影響は顕著ではない。最大せん断力時のせ ん断変位は付着長が短くなると值が小さくなる傾向が見 られる。

供試体の破壞状況，すなわち鋼繊維の破壊様式と繊維 付根部モルタルの破壞状況に関する結果は表一 4 に示さ れている。一軸引張の実験では，付着長によらず，すべ ての鋼繊維が引き抜けた。鋼繊維付根付近のモルタル部 分の破壊は, 繊維方向角が増加すると大きくなる傾向が あることがわかる。一方，せん断の実験では，付着長が 長い場合は鋼繊維が破断する割合が大きく，付着長が $4 \mathrm{~mm}$ と短い場合はすべての鋼繊維が引き抜けた。鋼繊 維付根付近のモルタル部分の破壞は, 付着長によらず, 破壊した部分の大きさは小さいことがわかる。

表-4 供試体の破壊状況（付着長用供試体）

\begin{tabular}{|c|c|c|c|c|c|c|c|}
\hline \multirow{2}{*}{ 蹇 } & \multirow[t]{2}{*}{ 供試体 } & \multicolumn{2}{|c|}{$\begin{array}{c}\text { 鋼繊維 } \\
\text { の破壊 }(\%)\end{array}$} & \multicolumn{4}{|c|}{$\begin{array}{c}\text { モルタルの破壊* }(\%) \\
\text { (破壊部長軸の長さ }(\mathrm{mm}) \text { ) }\end{array}$} \\
\hline & & 引抜 & 破断 & 0 & 3 未満 & 5 未満 & 5 以上 \\
\hline \multirow{6}{*}{$\begin{array}{l}\text { 軸 } \\
\text { 减 }\end{array}$} & $T-0-12.5$ & 100 & 0 & 70 & 29 & 1 & 0 \\
\hline & $T-0-8.0$ & 100 & 0 & 74 & 25 & 1 & 0 \\
\hline & $T-0-4.0$ & 100 & 0 & 79 & 20 & 1 & 0 \\
\hline & $T-45-12.5$ & 100 & 0 & 33 & 56 & 8 & 3 \\
\hline & $T-45-8.0$ & 100 & 0 & 32 & 60 & 7 & 1 \\
\hline & $T-45-4.0$ & 100 & 0 & 51 & 45 & 3 & 1 \\
\hline \multirow{3}{*}{ 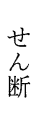 } & $S-0-12.5$ & 82 & 18 & 84 & 26 & 0 & 0 \\
\hline & $S-0-8.0$ & 92 & 8 & 83 & 17 & 0 & 0 \\
\hline & $S-0-4.0$ & 100 & 0 & 82 & 18 & 0 & 0 \\
\hline
\end{tabular}

[注］＊供試体不連続面に対するモルタル破壊部の投影形状を目視により 楕円近似して長軸の長さを計測した。

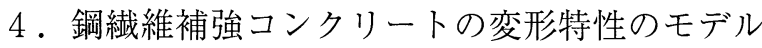
化

鋼繊維補強コンクリートが一軸引張またはせん断を受 ける場合の変形挙動をこれまでの実験結果をもとにモデ ル化する。なお，鋼繊維の形状は直線型（S1）を対象 とする。

\section{1 一軸引張特性のモデル化}

一軸引張特性に抢よほす繊維方向角の影響は, 図一 11 に示される ${ }^{4)}$ 。繊維方向角が増加するにともない, 最 大引張力が低下し，最大引張力時のひび割れ幅が増加す る傾向が見られる。

この実験結果をもとに，一軸引張特性は図一12のよ うにモデル化する。初期の弾性領域（区間 $\mathrm{OE}$ ), 最大 引張力までの付着破壊進行領域（区間 $\mathrm{EC}$ ), 最大引張力 直後の鋼瀻維破断または急激な付着破壊の領域（区間 $\mathrm{CB})$, 鋼繊維が徐々に引き抜ける領域（区間 $\mathrm{BP}$ )を, それぞれ直線で表す。鋼䋊維の繊維方向角の影響は, こ の多直線モデルの折曲り点を纎維方向角の関数とするこ とによりモデル化する。

鋼繊維の付着長の影響は図ー13のようにモデル化す
る。すなわち, 最大引張力と最大引張力時のひび割れ幅 が付着長に比例すると仮定する。

補正項は図ー14のようにモデル化する。すなわち， 最大引張力に達した後, 複数のひび割れの発生や局部破 壞の急激な進行を考慮して, 引張力が直線的に低減し, 軸方向変位がある程度大きくなった段階で一定值をとる ような補正項を仮定する。

一軸引張特性のモデルは以上のような仮定を重ね合わ せることによって得られる。軸方向変位 $u_{N} に$ 対する引 張力 $f_{N}$ を求める式は次のようになり，微小な変位増分に 対する荷重増分を求めることにより全体の荷重変位曲線 を求める。

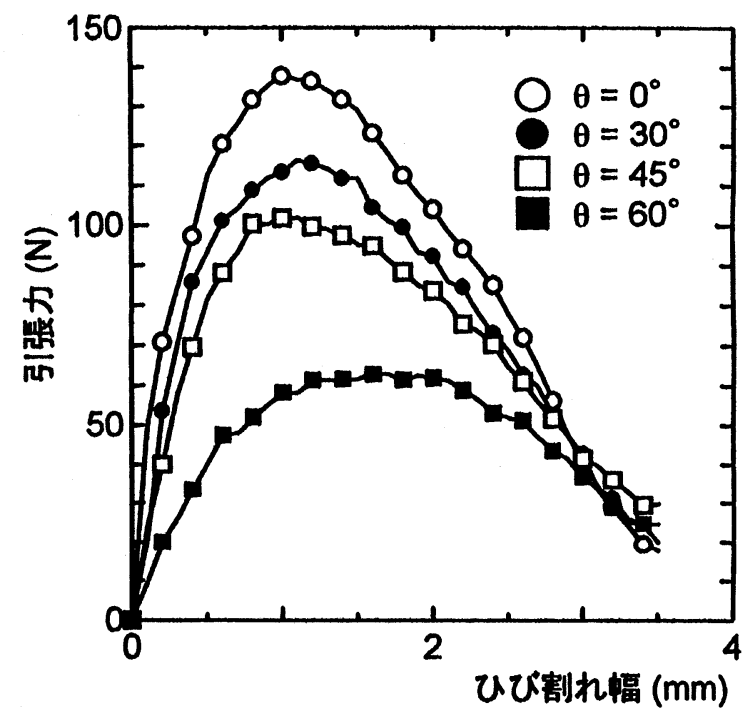

図-11 引張力とひび割れ幅の関係（繊維方向角の影響）

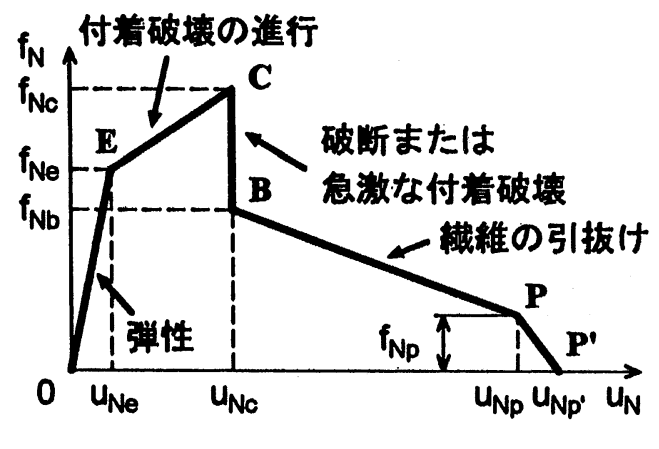

図一12 一軸引張特性のモデル化

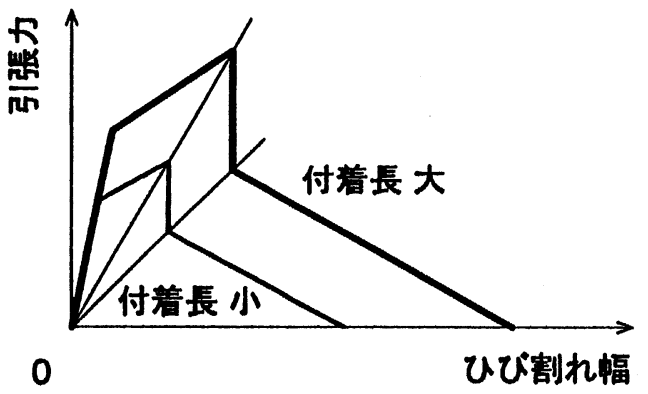

図一13一軸引張特性への付着長の影響 


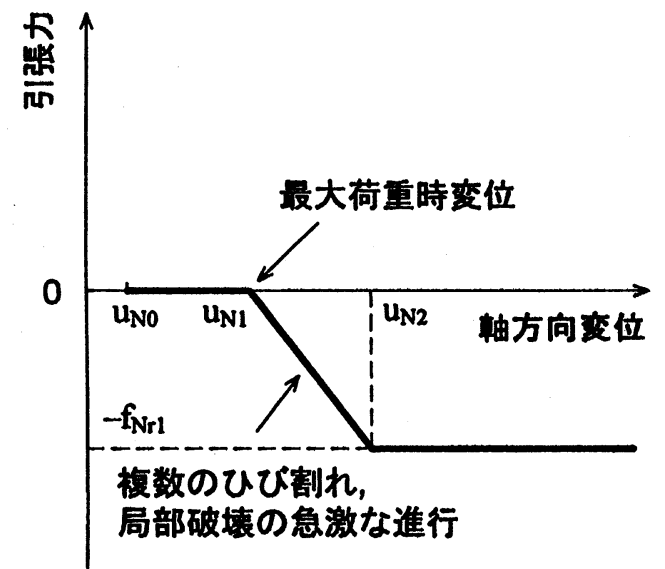

図一14 一軸引張特性の補正項

表一5 一軸引張特性のモデル化に用いた定数

\begin{tabular}{c|c|c|c|c|c|c|c}
\hline $\begin{array}{c}\theta \\
\left({ }^{\circ}\right)\end{array}$ & $\begin{array}{c}u_{\mathrm{Nc}} \\
(\mathrm{mm})\end{array}$ & $\begin{array}{c}f_{N c} \\
(\mathrm{~N})\end{array}$ & $n_{t}$ & $m_{t}$ & $\ell_{t}$ & $\begin{array}{c}u_{N p} \\
(\mathrm{~mm})\end{array}$ & $\begin{array}{c}f_{N p} \\
(\mathrm{~N})\end{array}$ \\
\hline 0 & 1.04 & 138.0 & 0.10 & 0.53 & 0.55 & 3.5 & 30.0 \\
\hline 30 & 1.29 & 116.0 & 0.18 & 0.53 & 0.55 & 3.5 & 28.0 \\
\hline 45 & 1.52 & 102.0 & 0.21 & 0.53 & 0.55 & 3.5 & 27.0 \\
\hline 60 & 1.84 & 62.8 & 0.25 & 0.53 & 0.55 & 3.5 & 26.0 \\
\hline
\end{tabular}

[注] $u_{N c}=n_{t} u_{N c}, f_{N c}=m_{t} f_{N c}, f_{N b}=\ell_{t} f_{N c}, u_{N p}=3.85 \mathrm{~mm}, f_{N p^{\prime}}=0 \mathrm{~N}$

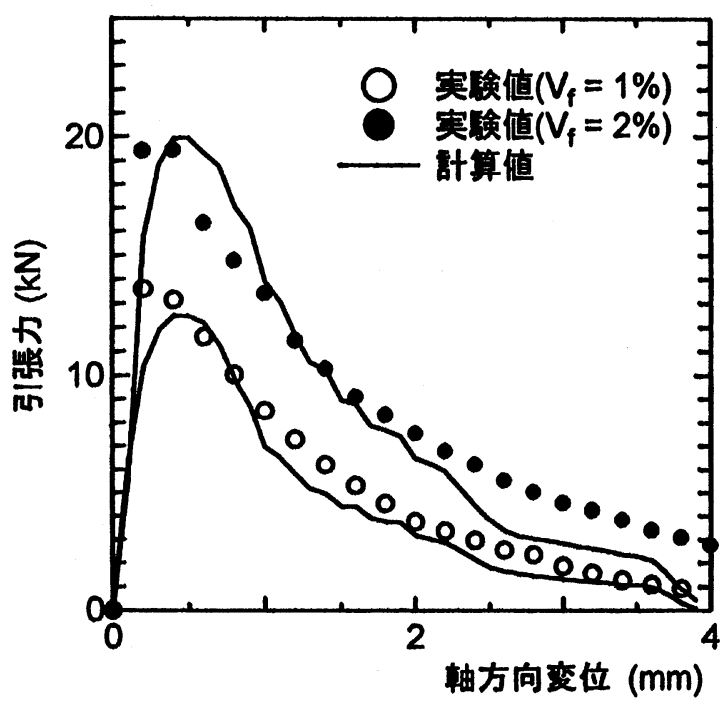

図ー15 一軸引張特性のモデルと実験值の比較

$$
\begin{aligned}
f_{N}\left(u_{N}\right)= & \sum_{i, j} f_{N}\left(u_{N}, \theta_{i}, \ell_{j}\right) w_{1}\left(\theta_{i}\right) w_{2}\left(\ell_{j}\right) N_{f} \\
& +f_{N m}\left(u_{N}\right)+f_{N r}\left(u_{N}\right)
\end{aligned}
$$

ここに, $f_{N}$ は鋼纎維補強コンクリートに作用する引張力, $f_{N f}$ は個々の鋼䋊維に作用する引張力, $u_{N}$ は引張力方向変 位， $w_{1}, w_{2}$ は繊維分布密度関数， $\theta_{i}$ は繊維方向角， $\ell_{j}$ は 付着長, $N_{f}$ は繊維総本数, $f_{N m}$ は母材が分担する荷重に 関する項, $f_{N r}$ は補正項である。式( 1 )の右辺の和は, 繊
維方向角 $\theta_{i}\left(0^{\circ}, 30^{\circ}, 45^{\circ}, 60^{\circ}\right)$, 付着長 $\ell_{j}(4.0 \mathrm{~mm}$, $8.0 \mathrm{~mm}, 12.5 \mathrm{~mm})$ についてとる。

$f_{N m}$ は， $u_{N}$ が 0 から $u_{N 0}$ の範囲で直線的に 0 から $f_{N r 1}$ ま で増加し，その後その值を一定に保つ。 $f_{N f}$ は，纎維方向 角 $\theta_{i}$, 付着長 $\ell_{j}$ ごとの挙動を多直線モデルで近似し, 各 折曲り点を纎維方向角と付着長の関数として表した。緎 維分布の割合を表す $w_{1} ， w_{2}$ は瀻維方向角と付着長につ いて均一分布とした。繊維方向角は $0^{\circ}$ から $+75^{\circ}$, 付着 長は $0 \mathrm{~mm}$ から半繊維長 $12.5 \mathrm{~mm}$ の範囲の值をとるもの とした。

引張力と軸方向変位の実験值と計算値の比較は図一 15 に示される。付着長の効果, 瀻維間の相互作用の効 果を取り入れることにより, 最大耐力時の変位と最大耐 力後の靸性を表すことができた。

なお，一軸引張特性のモデル化に用いた定数は表一 5 に示される。これらの值は実験により得られた引張力ー ひび割れ幅曲線から求められたものである。その他に用 いた定数は, 鋼繊維本数が, 実測した本数にもとづき $V_{f}=1 \%$ のとき 200 本， $V_{f}=2 \%$ のとき 400 本， $u_{N 0}=$ $0.1 \mathrm{~mm}, u_{N 1}=0.6 \mathrm{~mm}, u_{N 2}=1.0 \mathrm{~mm}, f_{N r 1}=5 \mathrm{kN}$ である。 このモデルの適用範囲は $u_{N} \leq 4 \mathrm{~mm}$ である。

\section{2 せん断特性のモデル化}

せん断特性におよほすす纎維方向角の影響は, 図一16 に示される4)。瀻維方向角 $\theta \leq 0$ の場合は, 最大せん断 力まで徐々に非線形的に到達し，その後せん断力がせん 断変位の増加にともない徐々に減少する傾向がある。一 方, 繊維方向角 $\theta>0$ の場合は, せん断力の増加が一度 止まり，せん断力がほほ一定となる区間が初期に見られ， その後, 再びせん断力がせん断変位とともに増加する。 最大せん断力に到達した後は, せん断力がせん断変位の 増加とともに徐々に減少する。

これらの実験結果をもとに，せん断特性は図一17の ようにモデル化する。繊維方向角 $\theta \leq 0$ の場合は, 初期 の弾性領域（区間 $\mathrm{OE}$ ), 最大せん断力までの付着破壞 進行領域 (区間 $\mathrm{EC}$ ), 最大せん断力直後の鋼瀻維破断ま たは急激な付着破壊の領域（区間 $\mathrm{CB}$ ), 鋼繊維が徐々に 引き抜ける領域（区間 BP）を，それぞれ直線で表す。

繊維方向角 $\theta>0$ の場合は, 初期の弾性領域（区間 $\left.O C^{\prime}\right)$ ，鋼纎維の局部的な座屈や支圧部母材の破壞によ るせん断力の減少する領域 (区間 $C^{\prime} B^{\prime}$ ), 安定化した領 域 (区間 $\left.B^{\prime} P^{\prime}\right)$ ，再度弾性的にせん断力が増加する領域 (区間 $\left.\mathrm{P}^{\prime} \mathrm{E}\right)$ ，付着破壞が進行する領域（区間 $\mathrm{EC}$ )，鋼繊 維の破断や急激な付着破壊が起こる領域（区間 $\mathrm{CB}$ ), 鋼 纎維が徐々に引き抜ける領域（区間 BP）を，それぞれ 直線で表す。鋼纎維の繊維方向角の影響は，この多直線 モデルの折曲り点を繊維方向角の関数とすることにより モデル化する。な押, 繊維方向角 $\theta>0$ の挙動は, 纎維 方向角 $\theta \leq 0$ の場合と異なっているが，これは $\theta=+$ $30^{\circ},+45^{\circ},+60^{\circ}$ の実験結果に基づくものである。 
纎維方向角 $\theta$ が $+30^{\circ}$ と $0^{\circ}$ の間では徐々に $\theta>0$ の挙動 から $\theta \leq 0$ の挙動に移行するものと仮定する。

鋼緘維の付着長の影響は図ー18のようにモデル化す る。すなわち, 最大せん断力は付着長によらず一定で, 最大せん断力時のせん断変位が付着長に比例すると仮定 する。

補正項は図ー19のようにモデル化する。ひび割れ幅 が小さい場合は鋼瀻維とモルタルの両方の作用でせん断 伝達が起こると考えられる。ひび割れ幅はせん断変位の

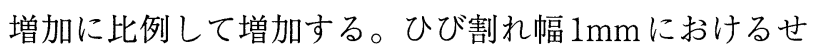
ん断変位は約 $1 \mathrm{~mm}$ である。せん断伝達の効果でせん断 力は増加し, せん断变位が所定の值に達するとせん断伝

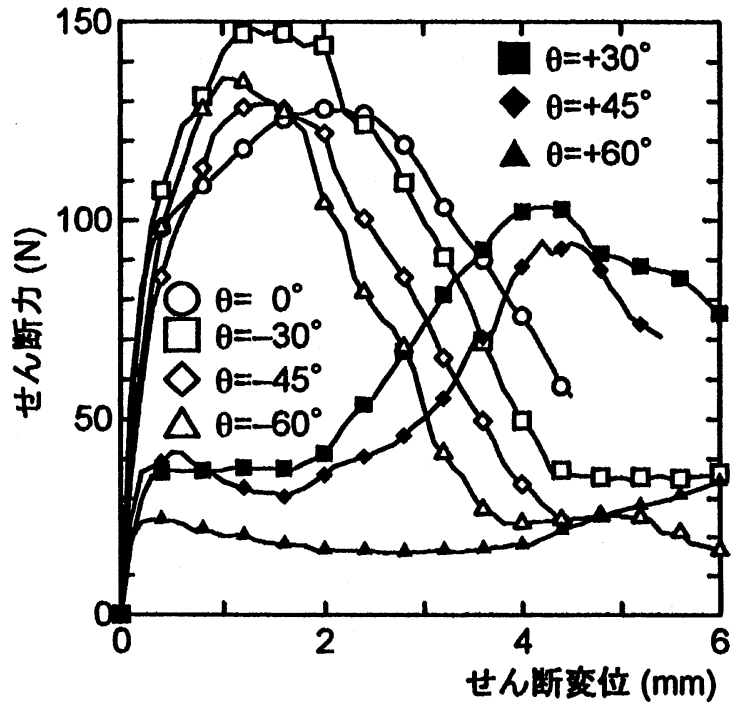

図ー16 せん断力とせん断变位の関係（繊維方向角の影響）
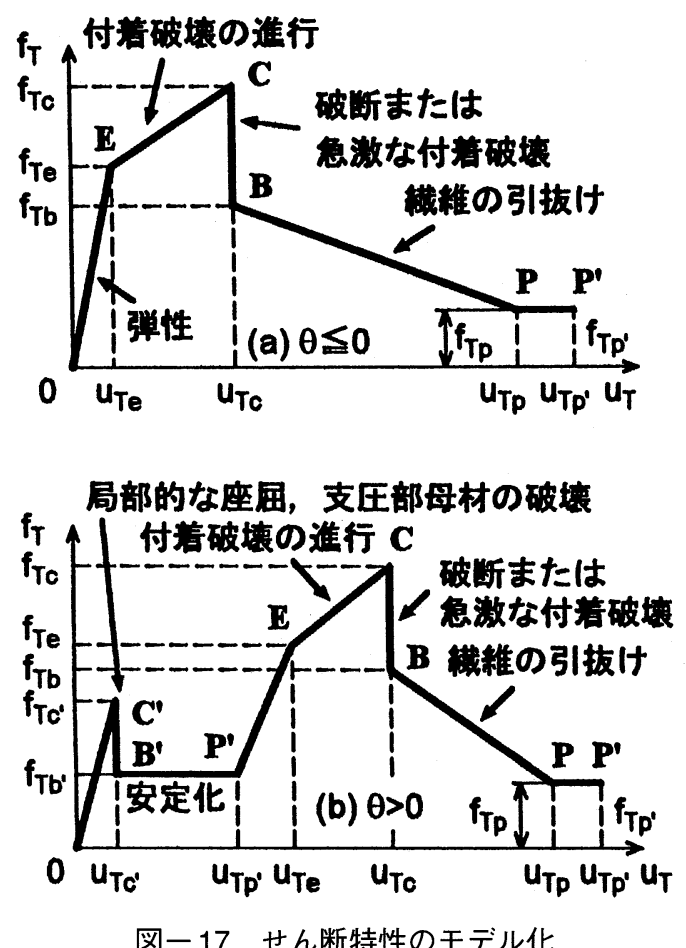
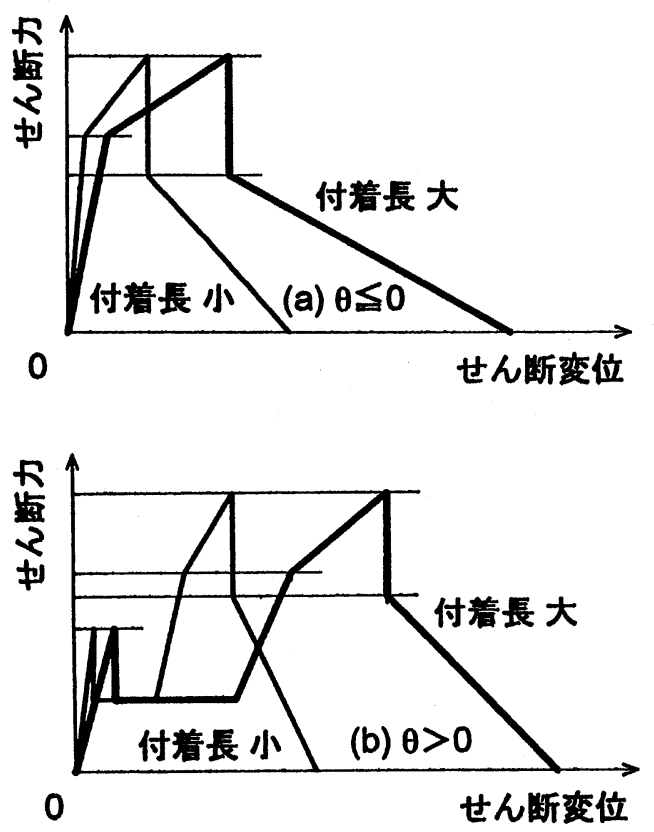

図一18 せん断特性モデルへの付着長の影響

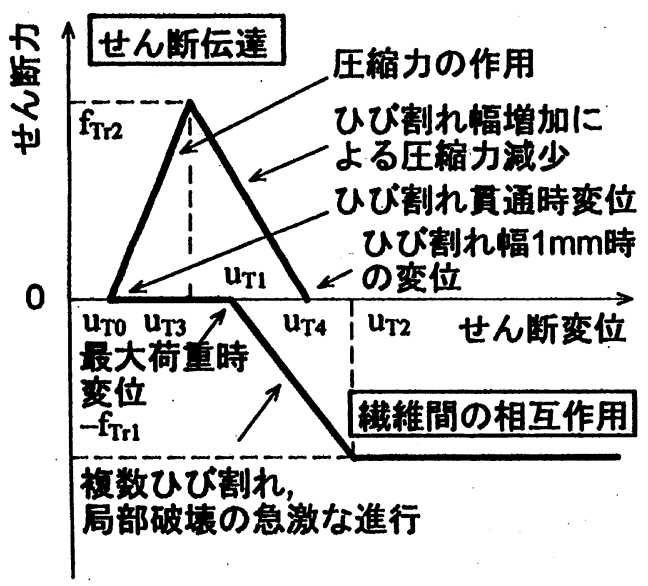

図一19 せん断特性の補正項

達の効果は減少し，ひび割れ幅が $1 \mathrm{~mm}$ でせん断伝達の 効果は 0 になると仮定する。一方，一軸引張の場合と同 様に，鋼繊維の相互作用は，最大せん断力後に複数のひ び割れや繊維間の局部的破壊によりせん断力が減少する ように仮定した。相互作用はある程度母材のモルタルの 劣化が進むと減少すると考え，せん断変位が所定の值に 達すると一定值になるようにした。

せん断特性のモデルは以上のような仮定を重ね合わせ ることによって得られる。せん断変位 $u_{T} に$ 対するせん 断力 $f_{T}$ を求める式は一軸引張に対する式と同様になり, 微小な変位増分に対する荷重増分を求めることにより全 体の荷重変位曲線を求める。

$$
\begin{aligned}
f_{T}\left(u_{T}\right)= & \sum_{i, j} f_{T J}\left(u_{T}, \theta_{i}, \ell_{j}\right) w_{1}\left(\theta_{i}\right) w_{2}\left(\ell_{j}\right) N_{f} \\
& +f_{T m}\left(u_{T}\right)+f_{T r}\left(u_{T}\right)
\end{aligned}
$$


ここに, $f_{T}$ は鋼繊維補強コンクリートに作用するせん断 力, $f_{7 g}$ は個々の鋼繊維に作用するせん断力, $u_{T}$ はせん断 変位, $w_{1}, w_{2}$ は瀻維分布密度関数, $\theta_{i}$ は繊維方向角, $\ell_{j}$ は付着長, $N_{f}$ は繊維総本数, $f_{T m}$ は母材が分担する荷 重に関する項， $f_{T r}$ は補正項である。式(2)の右辺の和は 纎維方向角 $\theta_{i}\left(0^{\circ}, \pm 30^{\circ}, \pm 45^{\circ}, \pm 60^{\circ}\right)$, 付着長 $\ell_{j}$ $(4.0 \mathrm{~mm}, 8.0 \mathrm{~mm}, 12.5 \mathrm{~mm})$ についてとる。

$f_{T m}$ は, $u_{T}$ が 0 から $u_{T 0}$ の範囲で直線的に 0 から $f_{T r 1}$ まで 増加し, その後その值を一定に保つ。 $f_{T J}$ は, 纎維方向角 $\theta_{i}$, 付着長 $\ell_{j}$ ごとの挙動を多直線モデルで近似し, 各 折曲り点を纎維方向角と付着長の関数として表した。繊 維分布の割合 $w_{1}, w_{2}$ は繊維方向角と付着長について均 一分布とした。纎維方向角は $-75^{\circ}$ から $+75^{\circ}$, 付着長 は $0 \mathrm{~mm}$ から半繊維長 $12.5 \mathrm{~mm}$ の範囲の值をとるものと した。

せん断力とせん断変位の実験值と計算値の比較は図一 20 に示される。付着長の影響, 繊維間の相互作用およ びせん断伝達の効果を考慮することにより，鋼纎維補強 コンクリートのせん断に対する挙動を表すことができ た。

なお，せん断特性のモデル化に用いた定数は表一6に 示される。これらの值は実験により得られたせん断力一 せん断変位曲線から求められたものである。その他に用 いた定数は，鋼緘維本数が，実測した本数にもとづき $V_{f}=1 \%$ のと 260 本,$V_{f}=2 \%$ のとき 560 本,$u_{T 0}=$ $0.1 \mathrm{~mm}, u_{T 1}=0.6 \mathrm{~mm}, u_{T 2}=1.0 \mathrm{~mm}, u_{T 3}=0.5 \mathrm{~mm}$, $u_{T 4}=1.0 \mathrm{~mm}, f_{T r 1}=30 \mathrm{kN}, f_{T r 2}=10 \mathrm{kN}$ である。このモデ ルの適用範囲は $u_{T} \leq 6 \mathrm{~mm}$ である。

以上のモデル化の計算で用いられた多直線モデルの折 曲り点の関係式は表一7に示される。これらの関係式で, 繊維方向角 $\theta$ の多項式は表一 5 および表一 6 に示されて いる実験值抢よび実験值から計算された值から最小二乗 法により求められたものである。表一 7 の式から計算さ れる值と表一 5 および表一 6 の実験值の相関係数の平均

表一6 せん断特性のモデル化に用いた定数

(a) $\theta \leq 0$

\begin{tabular}{c|c|c|c|c|c|c|c}
\hline $\begin{array}{c}\theta \\
\left({ }^{\circ}\right)\end{array}$ & $\begin{array}{c}u_{T_{c}} \\
(\mathrm{~mm})\end{array}$ & $\begin{array}{c}f_{T c} \\
(\mathrm{~N})\end{array}$ & $n_{s}$ & $m_{s}$ & $\ell_{s}$ & $\begin{array}{c}u_{T_{p}} \\
(\mathrm{~mm})\end{array}$ & $\begin{array}{c}f_{T_{p}} \\
(\mathrm{~N})\end{array}$ \\
\hline 0 & 2.2 & 140.0 & 0.10 & 0.72 & 0.83 & 4.6 & 55.0 \\
\hline-30 & 1.4 & 164.0 & 0.20 & 0.71 & 0.80 & 4.2 & 42.0 \\
\hline-45 & 1.3 & 134.0 & 0.40 & 0.79 & 0.84 & 4.0 & 33.0 \\
\hline-60 & 1.1 & 141.0 & 0.40 & 0.78 & 0.85 & 3.8 & 25.0 \\
\hline \multicolumn{7}{|c}{$(\mathrm{b})$} & $\theta>0$ \\
\hline $\begin{array}{c}\theta \\
\left({ }^{\circ}\right)\end{array}$ & $\begin{array}{c}u_{T_{c}} \\
(\mathrm{~mm})\end{array}$ & $\begin{array}{c}f_{T_{c}}^{\prime} \\
(\mathrm{N})\end{array}$ & $q_{s}^{\prime}$ & $r_{s}^{\prime}$ & $\begin{array}{c}u_{T_{c}} \\
(\mathrm{~mm})\end{array}$ & $\begin{array}{c}f_{T_{c}} \\
(\mathrm{~N})\end{array}$ & $q_{s}$ \\
\hline+30 & 0.75 & 46.7 & 0.60 & 2.1 & 3.42 & 104.3 & 0.55 \\
\hline+45 & 0.55 & 36.4 & 0.60 & 2.9 & 5.53 & 91.7 & 0.55 \\
\hline+60 & 0.35 & 26.1 & 0.60 & 7.1 & 8.61 & 79.1 & 0.55 \\
\hline
\end{tabular}

[注] (a) $u_{T_{e}}=n_{s} u_{T c}, f_{T_{e}}=m_{s} f_{T_{c}}, f_{T_{b}}=\ell_{s} f_{T,}, u_{T_{p}}^{\prime}=10 \mathrm{~mm}, f_{T_{p}^{\prime}}=30 \mathrm{~N}$ (b) $f_{T b}^{\prime}=q_{s}^{\prime} f_{T}^{\prime}, u_{T_{p}}^{\prime}=r_{s}^{\prime} u_{T c}^{\prime}, f_{T b}=q_{s} f_{T c}, u_{T_{p}}=10 \mathrm{~mm}, f_{T_{p}}=1.0 \mathrm{~N}$

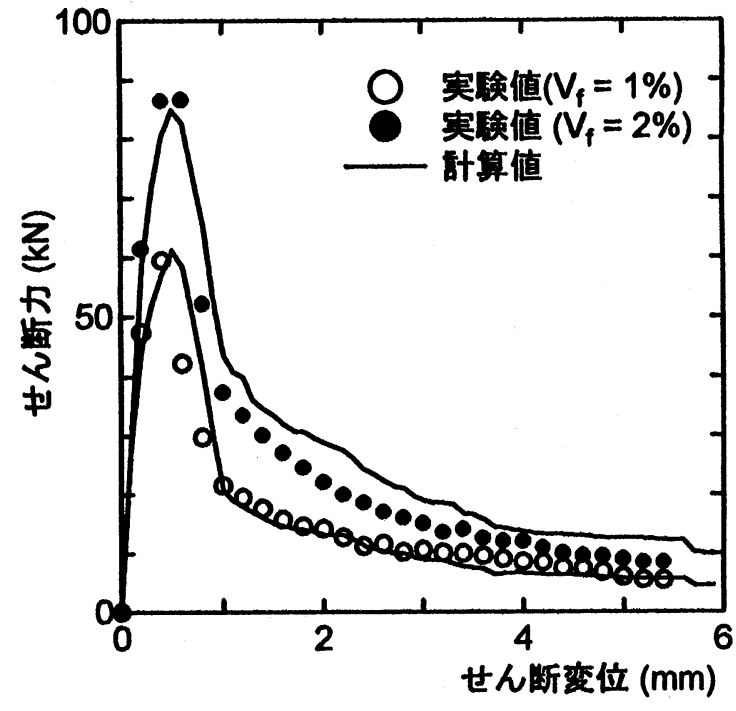

図一20 せん断特性のモデルと実験值の比較

\begin{tabular}{|c|c|}
\hline-7 & モデルに含まれる定数と織維方向角 $\theta$ の関係 \\
\hline 荷重 & パラメータの関係式 \\
\hline $\begin{array}{l}\text { 一軸 } \\
\text { 引張 }\end{array}$ & $\begin{aligned} u_{N c} & =0.232 \theta^{3}+0.182 \theta^{2}+0.318 \theta+1.05(\mathrm{~mm}) \\
f_{N c} & =-158 \theta^{3}+189 \theta^{2}-96.9 \theta+138(\mathrm{~N}) \\
n_{t} & =0.142 \theta+0.1 \\
m_{t} & =0.53 \\
\ell_{t} & =0.55 \\
u_{N p} & =3.5(\mathrm{~mm}) \\
f_{N p} & =30.0-3.82 \theta(\mathrm{N})\end{aligned}$ \\
\hline \multirow{4}{*}{$\begin{array}{l}\text { せん } \\
\text { 断 }\end{array}$} & (a) $\theta \leq 0$ \\
\hline & $\begin{array}{l}u_{T_{c}}=2.72 \theta^{3}+4.94 \theta^{2}+3.20 \theta+2.15(\mathrm{~mm}) \\
f_{T_{c}}=-455 \theta^{3}-803 \theta^{2}-343 \theta+140(\mathrm{~N}) \\
n_{s}=2.16 \theta^{3}+3.68 \theta^{2}+1.20 \theta+0.093 \\
m_{s}=1.00 \theta^{3}+1.74 \theta^{2}+0.672 \theta+0.714 \\
\ell_{s}=0.566 \theta^{3}+1.05 \theta^{2}+0.467 \theta+0.843 \\
u_{T_{p}}=0.666 \theta+4.52(\mathrm{~mm}) \\
f_{T_{p}}=28.7 \theta+55.7(\mathrm{~N})\end{array}$ \\
\hline & (b) $\theta>0$ \\
\hline & $\begin{aligned} u_{T_{c}}^{\prime} & =-0.764 \theta+1.15(\mathrm{~mm}) \\
f^{\prime}{ }_{c} & =-39.2 \theta+67.9(\mathrm{~N}) \\
\ell^{\prime} & =0.6 \\
r_{s}^{\prime} & =20.0 \theta^{3}-24.6 \theta^{2}+9.31 \theta+1.00 \\
u_{T_{c}} & =7.10 \theta^{2}-1.24 \theta+2.13(\mathrm{~mm}) \\
f_{T_{c}} & =-48.6 \theta+130(\mathrm{~N}) \\
\ell_{s} & =0.55 \\
u_{T_{p}} & =10.0(\mathrm{~mm}) \\
f_{T_{p}} & =1.0(\mathrm{~N})\end{aligned}$ \\
\hline
\end{tabular}

值は 0.98 である。

本モデルは直線型（S1）の鋼繊維を混入した鋼纎維 補強コンクリートの一軸引張とせん断に対する挙動を, ひび割れ面，せん断面に対する種々の纎維方向角と纎維 母材間の付着長に対する繊維単体の挙動を重ね合わせて 表現するものである。他の種類の鋼繊維についても，繊 維方向角と付着長の影響をもとに同様のモデルを構築す ることができると思われる。なお，一軸引張とせん断に 対する全体的な変形挙動, すなわち, 荷重一変位曲線の 形状パターンは, 図一6, 図ー7に示されるように, 絨 維の種類によらずほぼ同様である。 


\section{5. 結論}

鋼繊維補強コンクリートの変形特性を, 一軸引張とせ ん断を受ける場合について実験的に調べ，その変形挙動 をモデル化した。本研究の結果は次のようにまとめられ る。

（1）引張およびせん断を受ける鋼繊維補強コンクリート の変形特性は, 最大荷重および最大荷重時変位に対 して繊維形状の影響を受ける。

（2）鋼繊維補強コンクリートの挙動は，各繊維の挙動の 重ね合わせを基本とし，付着長の影響，相互作用の 影響などを考慮することにより表すことができる。

（3）角度ごとの荷重変位曲線は，多直線モデルで近似で きる。

謝辞 : 本研究の一部は, 文部省科学研究費補助金基盤研 究 $(\mathrm{C})$ により行われたことを付記し，謝意を表します。 また，本研究を実施するにあたり多大なご協力をいただ いた研究室の皆様に感謝いたします。

\section{参考文献}

1) Naaman, A.E. and Shah, S.P.: Pull-Out Mechanism in Steel Fiber-Reinforced Concrete, J. of Struct. Div., Proc. of ASCE, Vol.102, No.ST8, pp.1537-1548, 1976.

2) Ouyang, C., Pacios, A. and Shah, S.P.: Pullout of Inclined Fibers from Cementitious Matrix, J. of Engrg. Mech., ASCE,
Vol.120, No.12, pp.2641-2659, 1994.

$3 ）$ 椿龍哉・Sumitro, S.・庄司宏臣：鋼緘維補強コンクリート の引張およびせん断特性とモデル化，コンクリート工学論 文集, Vol.8, No.1, pp.233-241, 1997.

4）椿龍哉・荒井知久・Sumitro, S. : 鋼繊維補強コンクリート の一軸引張扔よびせん断に対する力学特性に及ぼす繊維特 性の影響，コンクリート工学論文集，Vol.10, No.2,pp.109118, 1999.

5）趙力采・小林一輔：鋼繊維補強コンクリートの引張強度試 験方法に関する研究，コンクリート工学，Vol.17, No.9, pp.87-95, 1979.

6) Kurihara, N., Uchida, Y., Kamada, T., Arakawa, T. and Rokugo, K.: Evaluation of Properties of Steel Fiber Reinforced Concrete by Means of Tension Softening Diagrams, Fracture Mechanics of Concrete Structures, Proc. of FRAMCOS-3, Vol.1, pp.465-476, 1998.

7 ) Sumitro, S. and Tsubaki, T.: Micromechanical Constitutive Relationship of Fiber Reinforced Concrete, Proc. of the Japan Concrete Institute, Vol.18, No.2, pp.419-424, 1996.

8 ) Stang, H., Li, Z. and Shah, S.P.: Pullout Problem: Stress versus Fracture Mechanical Approach, J. of Engrg. Mech., ASCE, Vol.116, No.10, pp.2136-2150, 1990.

9) Sumitro, S. and Tsubaki, T.: Micromechanical Fiber Pullout Model for Steel Fiber Reinforced Concrete, 土木学会論文 集, V, No.599/V-40, pp.155-163, 1998.

10) Sumitro, S. and Tsubaki, T.: Microfractural Pullout Model of Steel Fiber Reinforced Concrete, Fracture Mechanics of Concrete Structures, Proc. of FRAMCOS-3, Vol.1, pp.521530, 1998.

11) Naaman, A.E. and Najm, H.: Bond-Slip Mechanisms of Steel Fibers in Concrete, ACI Materials Journal, Vol.88, No.2, pp.135-145, 1991, Vol.89, No.1, pp.108-109, 1992.

12）JCI：繊維補強コンクリートの試験方法に関する規準，JCISF, pp.25-26, 31-33, 1984.

（原稿受理年月日：1999年 9 月 10 日）

Modeling of Deformational Behavior of Steel Fiber Reinforced Concrete under Uniaxial Tension and Shear

By Tatsuya Tsubaki, Tomohisa Arai and Takenori Yasunaga

Concrete Research and Technology, Vol.11, No.3, Sep., 2000

Synopsis The deformational behavior of steel fiber reinforced concrete is important because it affects the crack width which influences the durability of the structure. In this study the deformational behavior of steel fiber reinforced concrete subjected to uniaxial tension and shear was investigated experimentally. In the experiment the effects of the volumetric fiber content, the fiber geometry and the fiber embedment length were investigated. Highstrentgh concrete was used in the specimen. From the experimental results models for the deformational behavior of steel fiber reinforced concrete under uniaxial tension and shear were obtained.

Keywords : steel fiber reinforced concrete, uniaxial tension, shear, deformational behavior, fiber geometry, embedment length, modeling 